\title{
Bio Fuel: the Fuel of the Future
}

\author{
Jolly James and Ashwini Balasundaram, Member, IEDRC
}

\begin{abstract}
The world is running out of fossil fuels and is in search of alternate energy sources. This energy should be clean and green. Thus, bio fuel can be the fuel of the future as it is an option of environmentally sustainable energy source. Jatropha oil can be taken as a basic solution in this case in which the Jatropha curcas is converted into the valuable Jatropha oil through the process of Transesterification. This can be converted into a profitable business model with the increasing demand for alternate energy. The supply should meet the everyday demand of the public at strategic points replacing petro-diesel.
\end{abstract}

Index Terms-Bio fuel, alternate energy, Jatropha curcas, Transesterification, marketing mix of Jatropha.

\section{INTRODUCTION}

We live in a world of scarcity. That's what people say. The world is running out of energy sources, the non renewable sources are getting depleted etc. But if we see the broader picture this is a big opportunity. They say that necessity is the mother of all the inventions. And this world is abundant enough to sustain humanity for other million years. Thus, to make the surroundings eco-friendly and keep pace with the development we need alternate energy.

\section{PRoblem Statement}

The world is running out of non renewable sources of energy at a fast pace. People are looking for cheap sources of alternate energy which are both economically and environmentally sustainable. There is a great demand for green and clean energy because the usage of these non renewable sources is posing a great threat to the environment [1].

When we look at the energy statistics we can see that India has a voracious appetite for energy but a lack of supply for domestic energy resources. Currently about $35 \%$ of India's commercial energy requirements are imported [1].

The Government of India's (Gol) Planning Commission predicts dramatic demand increases for coal and oil over the next 20 years [1].

By the following data we can see that there is a huge requirement for energy but they are focusing more on the non renewable resources. And the pace at which these non renewable resources are depleting is pointing towards another World War. Thus, a nation needs to be self sufficient.

The major source of energy in India is coal. The coal and naptha based power projects are riding over other non

Manuscript received March 20, 2012; revised May 05, 2012.

Jolly James and Ashwini Balasundaram are with SRM School of Management, Chennai (email: ash16 bala@yahoo.com). conventional energy sources, but many environmental threats are associated with them. India stands 3rd in Green House Gas emissions. Developing nations are now the largest sources of green house gases. Apart from this the toxic emissions from the usage of coal are ruining historical monuments like Taj Mahal. And India has been known for the presence of a vivid history. Such toxic emissions are just hampering the preservation process.

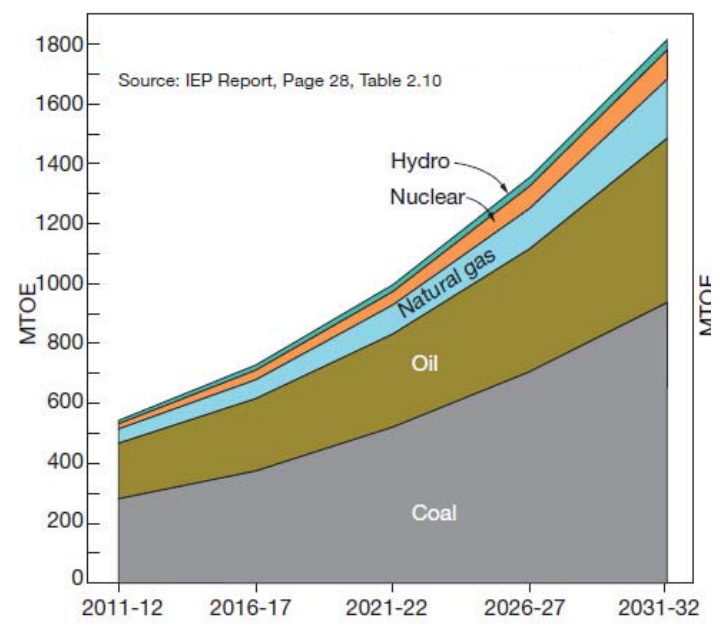

Fig. 1-1. Total energy requirements.

A very green and clean solution which can be offered is Bio Fuel. Bio Fuel is a type of fuel whose energy is derived from biological carbon fixation. It uses biological organisms to convert some sugar source to a Fuel of value. It includes fuels derived from bio mass conversion as well as solid bio mass, liquid fuels and various bio gases like methane, natural gas etc. Biodiesel provides $93 \%$ more usable energy than the fossil energy needed for its production, reduces GHGs by $41 \%$ compared with diesel, reduces several major air pollutants, and has minimal impact on human and environmental health through $\mathrm{N}, \mathrm{P}$, and pesticide release [2].

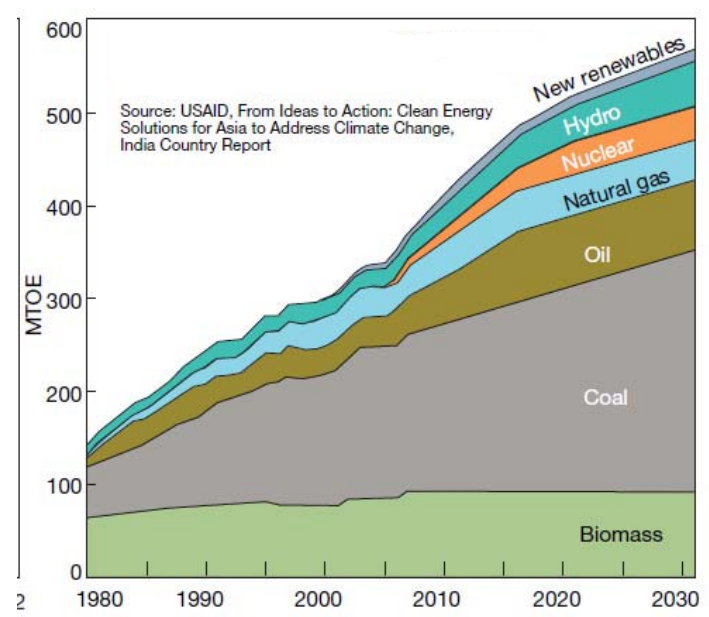

Fig. 1-2. Total primary energy bysource, 1980-2030. 


\section{OFFERED SOLUTION}

\section{Jatropha}

Jatropha is one of the options that come in everybody's mind when bio fuels are discussed. India has more than 50 million Hectares of wasteland, which could be utilized for cultivating plants. Jatropha is a kind of plant which can come up on arid land, albeit with lower yield. Off late many agencies are coming up offering technical support and helping in the buying process. Currently the oil from Jatropha curcas seeds is used for making bio fuel in Philippines and in Brazil, where it grows naturally and in plantations in the southeast, north, and northeast of Brazil [4]. Likewise, Jatropha oil is being promoted as an easily grown bio fuel crop in hundreds of projects throughout India and other developing countries. Large plantings and nurseries have been undertaken in India by many research institutions, and by women's self-help groups who use a system of microcredit to ease poverty among semiliterate Indian women. The railway line between Mumbai and Delhi is planted with Jatropha and the train itself runs on $15-20 \%$ biodiesel. In Africa, cultivation of Jatropha is being promoted and it is grown successfully in countries such as Mali. In the Gran Chaco of Paraguay, where a native variety (Jatropha matacensis) also grows, studies have shown the suitability of Jatropha cultivation and agro producers are starting to consider planting in the region. Estimates of Jatropha seed yield vary widely, due to a lack of research data, the genetic diversity of the crop, the range of environments in which it is grown, and Jatropha's perennial life cycle. Seed yields under cultivation can range from 1,500 to 2,000 kilograms per hectare, corresponding to extractable oil yields of 540 to 680 litres per hectare (58 to 73 US gallons per acre). Time magazine recently cited the potential for as much as 1,600 gallons of diesel fuel per acre per year. Jatropha can also be intercropped with other cash crops such as coffee, sugar, fruits and vegetables. There is scepticism about the miracle properties of Jatropha. For example: "The idea that Jatropha can be grown on marginal land is a red herring," according to Harry Stourton, business development director of UK-based Sun Bio fuels, which cultivates Jatropha in Mozambique and Tanzania. "It does grow on marginal land, but if you use marginal land you'll get marginal yields," he said [12].

\section{The COST InVOLVED}

The cost of Bio Diesel is largely dependent on the choice of feedstock and the size of the production facility. In India, approximate $85 \%$ of the operating cost of biodiesel plant is the cost to acquire feedstock. Securing own feedstock to insure supply at a fair price and sourcing it locally to avoid long haulage for delivery of seeds to biodiesel plant are critical factors in controlling profitability [4].

For an optimal capacity of 10,000 TPA of biodiesel, the capital cost for oil extraction \& transesterification would be Rs.20,000/T capacity. The cost of oil extraction has been estimated as Rs.2360/MT and cost of transesterification at Rs.6670/MT with by-products produced @ 2.23 MT seed cake per ton of biodiesel and $95 \mathrm{Kgs}$. of glycerol per ton of biodiesel. The return on investment (ROI) has been arrived at $15 \%$ pretax on the capital cost [4].

\begin{tabular}{|c|c|c|c|}
\multicolumn{4}{|c}{ TABLE I: RATES OF POTENTIAL BIO FUELS } \\
\hline Feedstock & Country & $\begin{array}{c}\text { Yield/hectare } \\
(\mathrm{kg})\end{array}$ & $\begin{array}{c}\text { Rate per } \\
\text { barrel(US \$) }\end{array}$ \\
\hline Soya Oil & USA & 375 & 73 \\
\hline $\begin{array}{c}\text { Rapeseed } \\
\text { Oil }\end{array}$ & Europe & 1000 & 78 \\
\hline $\begin{array}{c}\text { Jatropha } \\
\text { Oil }\end{array}$ & India & 3000 & 43 \\
\hline Palm Oil & Malaysia & 5000 & 46 \\
\hline
\end{tabular}

\begin{tabular}{|c|c|c|c|c|c|c|c|}
\hline Year & $\begin{array}{l}\text { Diesel } \\
\text { Demand } \\
(\mathrm{MMT})\end{array}$ & $\begin{array}{c}\text { Bio } \\
\text { diese } \\
1 @ \\
5 \% \\
\text { MM } \\
\text { T }\end{array}$ & $\begin{array}{c}\text { Are } \\
\text { a } \\
\text { for } \\
5 \% \\
\text { Mh } \\
\text { a }\end{array}$ & $\begin{array}{c}\text { Bio } \\
\text { diese } \\
1 @ \\
10 \% \\
\mathrm{MM} \\
\mathrm{T}\end{array}$ & $\begin{array}{c}\text { Are } \\
\text { a } \\
\text { for } \\
10 \\
\% \\
\text { Mh } \\
\text { a }\end{array}$ & $\begin{array}{c}\text { Bio } \\
\text { diese } \\
1 @ \\
20 \% \\
\text { MM } \\
\text { T }\end{array}$ & $\begin{array}{c}\text { Are } \\
\text { a } \\
\text { for } \\
20 \\
\% \\
\text { Mh } \\
\text { a }\end{array}$ \\
\hline $\begin{array}{c}2005 \\
-06\end{array}$ & 49.56 & 2.48 & 2.07 & 4.96 & 4.14 & 9.19 & $\begin{array}{c}8.2 \\
8\end{array}$ \\
\hline $\begin{array}{c}2006 \\
-07\end{array}$ & 52.33 & 2.62 & 2.19 & 5.23 & 4.38 & $\begin{array}{c}10.4 \\
7\end{array}$ & $\begin{array}{c}8.7 \\
6\end{array}$ \\
\hline $\begin{array}{c}2011 \\
-12\end{array}$ & 66.90 & 3.35 & 2.79 & 6.69 & 5.58 & $\begin{array}{c}13.3 \\
8\end{array}$ & $\begin{array}{r}11 . \\
19\end{array}$ \\
\hline
\end{tabular}

The R\&D Centre is now taking a number of initiatives for promotion of biodiesel in the country. A state-of-the art quality control laboratory has been set up to check the quality of biodiesel, as per ASTM/BIS specifications. Indian Oil has entered into an MOU with Indian Railways for plantation of Jatropha on railway land. It is also setting up 10 biodiesel procurement centres. A reduction of 10 to $15 \%$ in smoke density has been observed with the use of biodiesel blends [3].

\section{THE Business IDEA}

The whole business idea is about how to make use of bio fuels with gasoline so that we can provide cheaper, greener and cleaner fuel. The bio fuel industry is yet to be matured and hence is a great opening towards a new era of ecofriendly fuel within the domestic boundaries of the country. The product is still in its introduction stage and hence there is a bright future for it. Thus, proper infrastructure is needed for the development of this market. A 'Jatropha extraction plant' is to be set up using the sophisticated technology available for meeting the future demand. In an attempt to revive India's Bio-diesel industry, country's Ministry of New and Renewable Energy (MNRE) and Confederation of Indian industry (CII) have recommended price increase for bio-diesel from Jatropha [13].

According to a study done by the ministry along with CII, price of Bio-diesel from Jatropha needs to be raised to Rs 36 /litre from the present 26.50/litre to make it sustainable and for suitable growth of the Indian Bio-diesel industry [4].

The study estimates that if the blending initiative of $2 \%$ Jatropha based Biodiesel are achieved in year 2011-12, India will save around Rs. 3000 crores and will generate revenue of around Rs. 5500 crores in the rural economy with an opportunity of investment to the extent of Rs. 1700 crores on an annual basis. This initiative would also help in reduction of Green House Gas emission by 3 Million Metric 
Tonnes (MMT) on an annual basis [5].

This is a window of opening for the Jatropha Industry. The land available for Jatropha curcas plantations (million hectares) Thus, the utilization of these lands will yield fruitful results in future [5].

\begin{tabular}{|c|c|c|c|c|c|c|c|}
\hline $\begin{array}{l}\text { Forest } \\
\text { areas }\end{array}$ & $\begin{array}{l}\text { Agric } \\
\text { ulture } \\
\text { (boun } \\
\text { dary } \\
\text { planta } \\
\text { tion) }\end{array}$ & $\begin{array}{l}\text { Agricul } \\
\text { ture } \\
\text { (agrifo } \\
\text { restry) }\end{array}$ & $\begin{array}{l}\text { Culti } \\
\text { vable } \\
\text { fallo } \\
\text { w } \\
\text { lands }\end{array}$ & $\begin{array}{l}\text { Wast } \\
\text { eland }\end{array}$ & $\begin{array}{l}\text { Str } \\
\text { ip } \\
\text { la } \\
\text { nd } \\
\text { s }\end{array}$ & $\begin{array}{l}\text { To } \\
\text { tal }\end{array}$ & $\begin{array}{l}\text { Addit } \\
\text { ional } \\
\text { waste } \\
\text { land }\end{array}$ \\
\hline 3.0 & 3.0 & 2.0 & 2.4 & 2.0 & 1.0 & $\begin{array}{l}13 . \\
4\end{array}$ & 4.0 \\
\hline
\end{tabular}

\section{Cost Benefit AnALysis}

Now as jet fuel price has been increased people are moving towards bio fuel and up to 2017 aviations are trying to pull out whole system and make it run on bio fuel and even defence forces are also going to move towards bio fuel. So it is clearly visible that there is a huge scope for bio fuel.

TABLE III: COST INVOLVED IN A BIO FUEL PLANT

\begin{tabular}{|c|c|}
\hline Particulars & Amount \\
\hline Land (25 acres) & $70,000,000$ \\
\hline Farm preparations & $30,34,900$ \\
\hline Building Construction & $11,395,000$ \\
\hline Oil Extraction and purifications plant & $55,40,000$ \\
\hline Oil collection Tanks & $90,90,000$ \\
\hline Pre-oil processing plant & $95,59,750$ \\
\hline Biodiesel Production Rector & $15,200,392$ \\
\hline Fatty acid fraction plant & $92,79,780$ \\
\hline Glycerol purification units & $80,90,600$ \\
\hline Biodiesel collection and post processing & $17,032,376$ \\
\hline plant & $85,79,000$ \\
\hline Operating systems & $10,720,750$ \\
\hline Equipment installation charge & $15,790,890$ \\
\hline Other lab. Instruments (R\&D) & $\mathbf{2 2 1 , 9 6 3 , 7 0 8}$ \\
\hline Total &
\end{tabular}

\section{JATROPHA MARKETING MIX MODEL IN INDIAN SCENARIO}

\section{A. The Economic Benefits of Jatropha \\ 1) Jatropha Oil}

The basic usage is of as of an alternative fuel. This can be promoted by spreading awareness about this fuel and making it available in the form of fuel stations at strategic points like petro-diesel. The pricing should be competitive so that the cost is covered and benefits are derived. And economy pricing should be used as a strategy for gaining a larger market share. The lower prices would grab public attention and make the usage of green fuels popular. Other promotional techniques like advertisements, spreading awareness through printing messages on t-shirts etc. could be used for spreading word about the progress of this ongoing research and development [7].

\section{2) Press Cake}

This is a by-product of Jatropha oil which is generally used as an animal feed. The other uses of this by-product are as a fertilizer, as a source for bio gas and can replace the usage of firewood. India has been using bio gas plants since ages. These plants are run through the cow dung. But the press cakes generate biogas much faster than the conventional cow dung due its carbon: nitrogen composition. This gives a new business opportunity which is capable of generating electricity and employment. By becoming energy efficient in the field of electricity many villages can get a constant and cheaper supply of electricity. Also its effluent slurry provides good organic manure with rich manorial properties. The lab studies reveals that a combination of $75 \%$ cattle dung and 25\% Jatropha oil cake gives best results [8].

3) Soap

Jatropha oil has anti-microbial properties and if used as soap is proven to be more active to get rid of the S. aureus and E. coli than any other plant-oil based soap. Adding other ingredients such as essential oil, gives relaxing sensation, and heals some skin problems such as acne, eczema related to fungi and others, making the soap a healthy natural choice to use. This gives another business opening for range of new soaps for any company. Just like jojoba, Jatropha soaps can grab a new share of market [9].

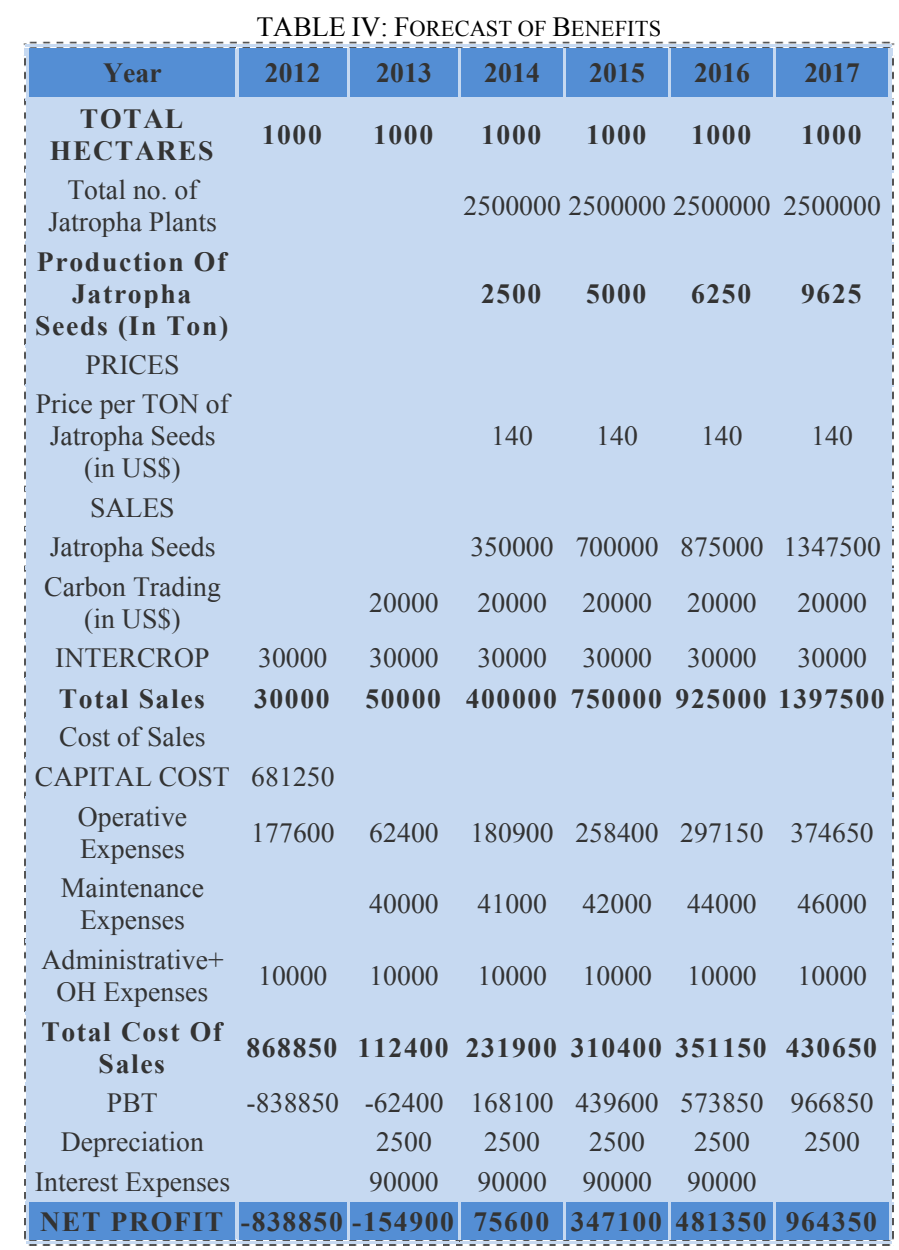

\section{4) Glycerol}

Purified glycerol can be used cement grinding aid which gives finer cement. This gives a better quality cement at cheaper processing charges [10].

\section{5) Medicinal Products}

Jatropha has been also used as a traditional folk medicine in many countries. Jatropha Curcas is a source of several secondary metabolites of medicinal importance. The leaf, fruits, latex and bark contain glycosides, tannins, 
phytosterols, flavonoids and steroidal sapogenins that exhibit wide ranging medicinal properties. Commercial exploitation for biopharmaceuticals is one of the prospective future potential of this plant [11].

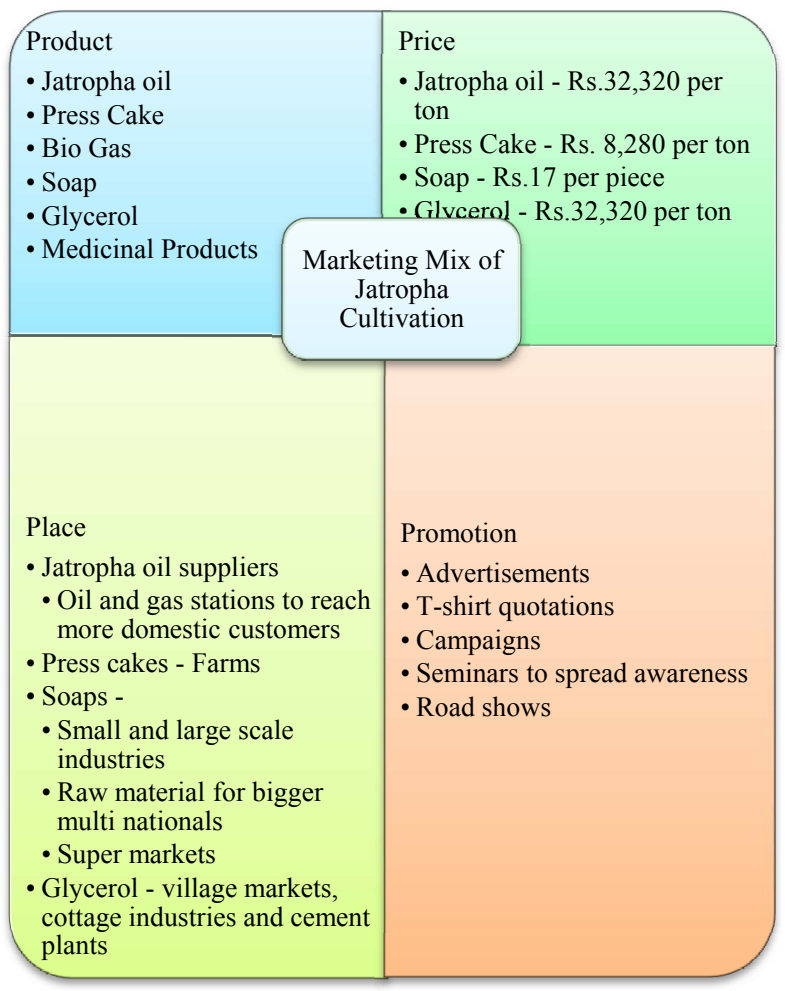

Fig. 3. Marketing mix of jatropha production.

These extra benefits make way for many new small scale businesses to flourish leading to the reduction of unemployment.

- This also leads to rural uplift and social benefits. By intercropping Jatropha with other cash crops, agriculture sector can again make a greater grip in the Indian GNP [5].

- As Jatropha can be grown in wastelands too, Indian barren lands can be covered with a green belt [5].

- There are many Jatropha oil plants coming up. To make this readily available to the large consumer market petrol bunks should be equipped with special tanks for bio diesel. According to statistical data: transport companies, wholesalers, and other organizations, whose annual consumption of biodiesel may exceed Rs. 64,634/- For this reason, the market for biodiesel is worth an estimated 150 million Rs in 2011 , and is projected to grow at $37 \%$ per year [5].

- Biodiesel is safe to handle and transport because it is as biodegradable as sugar (pure biodiesel degrades $85 \%$ to $88 \%$ in water within 28 days), 10 times less toxic than table salt (lethal dose is greater than $17.4 \mathrm{~g} / \mathrm{kg}$ body weight, while for salt ( $\mathrm{NaCL}$ ) it is $1.8 \mathrm{~g} / \mathrm{Kg}$ ), and has a high flashpoint of about $200^{\circ} \mathrm{C}$ compared to petroleum diesel fuel, which has a flash point of $70^{\circ} \mathrm{C}$ [5].

- Combustion of biodiesel provides over a $75-90 \%$ reduction in environmental pollution and a $90 \%$ reduction in cancer risks [5].

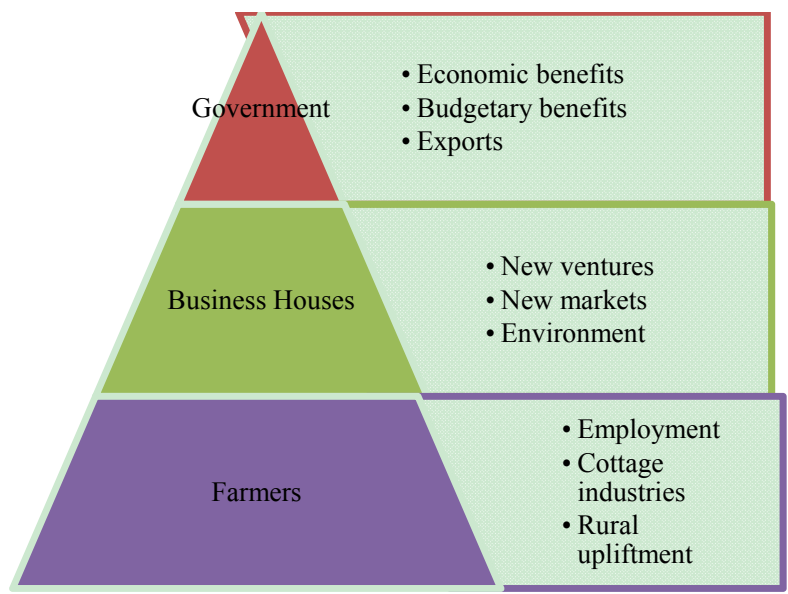

Fig. 4. Beneficiaries of this business model.

\section{LOGISTICS AND BUSINESS ANALYSIS}

India's major expense is towards importing crude oil which is leading to budgetary deficits. The major competitor to the bio fuel market is the petro-diesel market. Though it is subject to excise and taxes, it is till date the most conventional source of fuels in the market. Thus, the major problem is to make bio fuel readily available to the public just like any other form of fuel. The positioning of Bio fuel in the Indian market should be such that it provides benefit to the country both environmentally and economically [4].

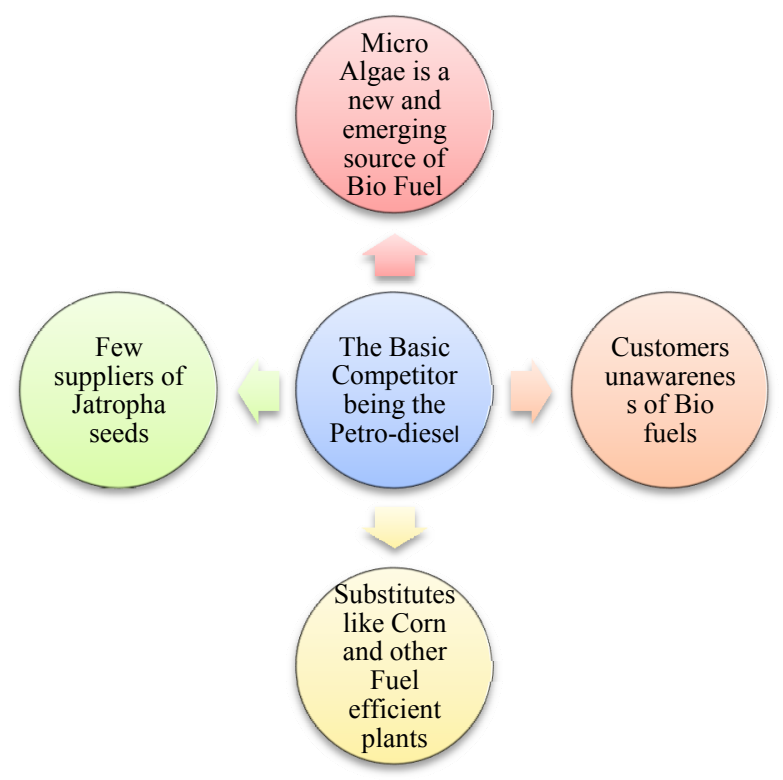

Fig. 5. Five forces analysis of Jatropha business.

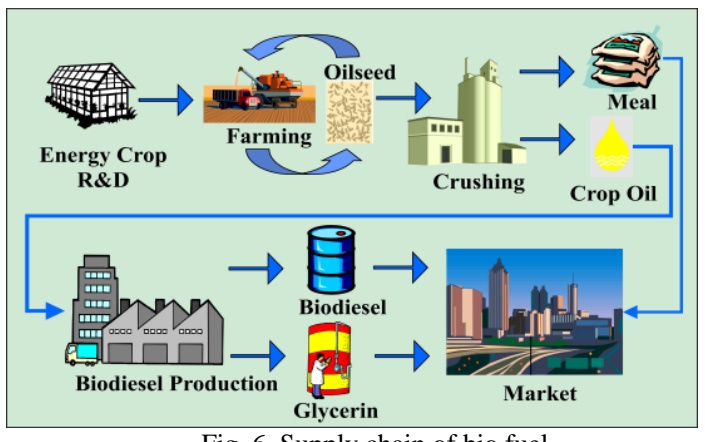

Fig. 6. Supply chain of bio fuel. 
The route which will be followed to make Jatropha oil and its by-products available to the potential market is as shown below [5]:

\section{Global MARKet ScEnARIO}

A new research predicts the global bio fuels market would double over the next decade, from $\$ 82.7$ billion in 2011 to $\$ 185.3$ billion in 2021 .

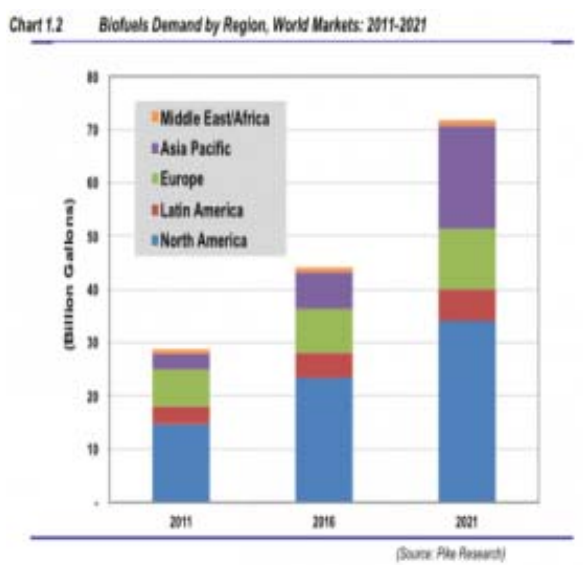

Fig. 7. Global demand of bio fuel.

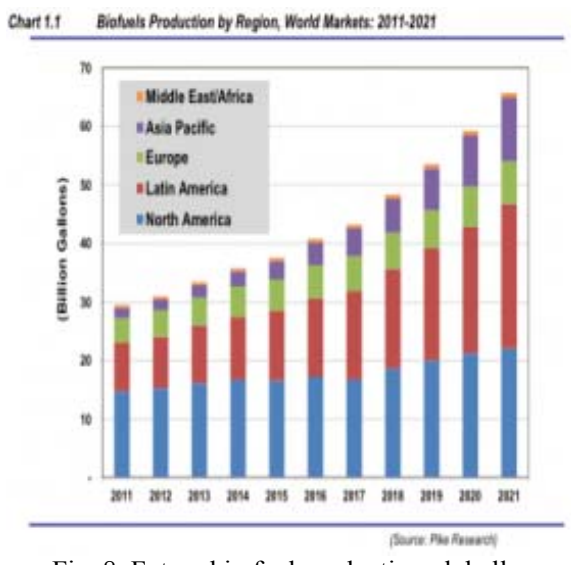

Fig. 8. Future bio fuel production globally.

Although growth is expected to climb steadily through 2016, more robust growth is expected between 2017 and 2021 , as a combination of higher oil prices, emerging mandate obligations, availability of new feedstocks, and the scaling up of advanced technologies drive increased investment in the industry [14].

\section{CONClusion}

As per the study we can see that the market prospects for getting Jatropha oil business in the main stream for making it beneficial for the current Indian Economy. This marketing model provides various pathways as to how go about making the Bio Fuels- the fuel of the future. Thus, if this bio-tech research goes hand in hand with the management and business openings in India, India could take another step towards being the economic super-power.

\section{ACKNOWLEDGEMENTS}

Thanks to Dr. Anand Anandkumar, MD and Chairman, Cell Works, Bengaluru and Dr. Sanjana Patel, senior bio modeling scientist, Cell Works, Bengaluru, for their time and support. And SRM university for their encouragement.

\section{REFERENCES}

[1] National Statistical Organization, Ministry of Statistics and Programme Implementation, Government of India, 2011.

[2] D. M. Kammen, The Rise of Renewable Energy, 2006.

[3] http://www.iocl.com/aboutus/research_development.aspx

[4] www.Jatrophabiodiesel.org

[5] Business plan on: Manufacturing of biodiesel and by products from Jatropha curcas, Shailesh Bhalara (dept. of biotechnology) Anjani Dhrangadhariya (dept. of bioinformatics) Zeophuen Sahoo (dept. of microbiology), Christ college Rajkot, 2011.

[6] www.oilgae.com

[7] K. M. Rahman, M. Mashud, Md. Roknuzzaman, and A. Al Galib, "Biodiesel from Jatropha oil as an alternative fuel for diesel engine,' vol. 10 , no. 03 .

[8] Bio-methanisation of Jatropha curcas defatted waste, Nafisa Ali, A. K. Kurchania and Swati Babel, 2010.

[9] G. B. Adebayo, O. M. Ameen, and L. T. Abass, Physico-chemical properties of biodiesel produced from Jatropha Curcas oil and fossil diesel, 2011.

[10] Utilization of Glycerol Derived from Jatropha's, Biodiesel Production as a Cement Grinding Aid O. Farobie, S S. Achmadi, and L K. Darusman, 2012.

[11] http://www.Jatrophabusiness.com/Jatropha-As-Medicinal-Plant.html

[12] phys.org

[13] www.bar.gov.ph

[14] Green Car Congress, Pike Research, 2012

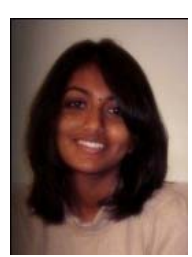

Jolly James is a member of IEDRC. She was born in Rajkot on 17th September 1990. She is pursuing her MBA in finance and marketing from SRM School of Management, Chennai and has completed her graduation in B.Com from Christ College Rajkot.

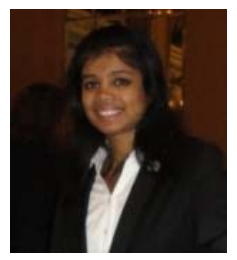

Ashwini Balasundaram member of IEDRC, was born and brought up in Chennai. She is pursuing her MBA in finance and marketing from SRM School of management and has completed her B.Com from MOP Vaishnav College, Chennai. She has been an aggressive debater and has represented various countries in prestigious events like HNMUN 2012. 